http://kitaibelia.unideb.hu/

ISSN 2064-4507 (Online) • ISSN 1219-9672 (Print)

(C) 2015, Department of Botany, University of Debrecen, Hungary

21 (1): 51-54.; 2015

DOI: $10.17542 /$ kit.51

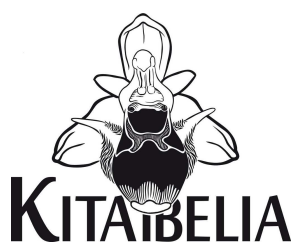

\title{
Az Orchis mascula subsp. signifera (Vest) Soó újrafelfedezése a Keszthelyi-hegységben
}

ÓVÁRI Miklós

\author{
H-8900 Zalaegerszeg, Gorkij u.1/d; miki58@indamail.hu \\ Rediscovery of Orchis mascula subsp. signifera (Vest) Soó \\ in the Keszthely Mts (Transdanubia, Hungary)
}

\begin{abstract}
Orchis mascula subsp. signifera is a rare, legally protected and endangered species of the Hungarian flora. Currently it is recorded from 25 flora mapping grid cell in Hungary. The westernmost Hungarian occurrence of the species was documented by a voucher collected by Dénes Gotthárd in 1976. After four decades the occurrence of $O$. mascula in the Keszthely Mts was confirmed in 2015. The local habitat preference and major threats to the taxon are briefly discussed.
\end{abstract}

Keywords: Castanea sativa stand, conservation, endangered species, Keszthely Mts, Orchidaceae

Összefoglalás: A hazai orchideaflóra egyik ritka, védett és veszélyeztetett képviselője az Orchis mascula subsp. signifera, amelynek 2015-ben egy négy évtizeddel korábbi, példánnyal dokumentált (Gotthárd Dénes, 1976) előfordulását sikerült újra megerősíteni a Keszthelyi-hegységben. A tárgyalt lelőhely a taxon magyarországi elterjedésének szélén helyezkedik el. A közlemény bemutatja a lelőhely aktuális termőhelyi viszonyait és veszélyeztető tényezőit.

Kulcsszavak: Keszthelyi-hegység, Orchidaceae, szelídgesztenye-liget, természetvédelem, veszélyeztetett faj

\section{Bevezetés}

A füles kosbor (Orchis mascula subsp. signifera) a hazai orchideaflóra egyik ritka faja, aktuális elterjedése a Középhegységekre korlátozódik, jelenlegi előfordulása mindössze 25 flóratérképezési fókvadrátban ismert (MoLNÁR V. 2012). Hazánkban napjainkban ismert legnyugatibb előfordulásai a Déli-Bakonyban vannak (MolnÁr V. 2011). A taxont a Keszthelyi-hegységből korábban nem közölték, de itteni előfordulására utal egy, a gyöngyösi Mátra Múzeum herbáriumában őrzött példánya (MolnÁr V. et al. 2012, 1. ábra A.). A lapon található 7 virágzó hajtást Gotthárd Dénes gyűjtötte 1976. május 31-én, „Lesenceistvánd, Gesztenyés, nyirkos erdőben" helymegjelöléssel. Mivel a faj a Keszthelyi-hegységből korábban nem volt ismert, szükségesnek látszott az adat ellenőrzése, az állomány felkutatása.

\section{A régi-új lelőhely}

2015. május 04-én, Lesenceistvánd határában, a Kő-orrán található kis kiterjedésű szelídgesztenye-ligetben az Orchis mascula subsp. signifera 29 példányát találtam (1. ábra B-D.), így a négy évtizedes adat, egyben a faj hazai legnyugatibb előfordulása megerősítésre került. Az állománynak 9 példánya virágzott, amelyek virágzó hajtásai (18-)35(-45) cm magasak és (15-)19(-25) virágúak voltak, tőleveleik száma 3-4 volt. 

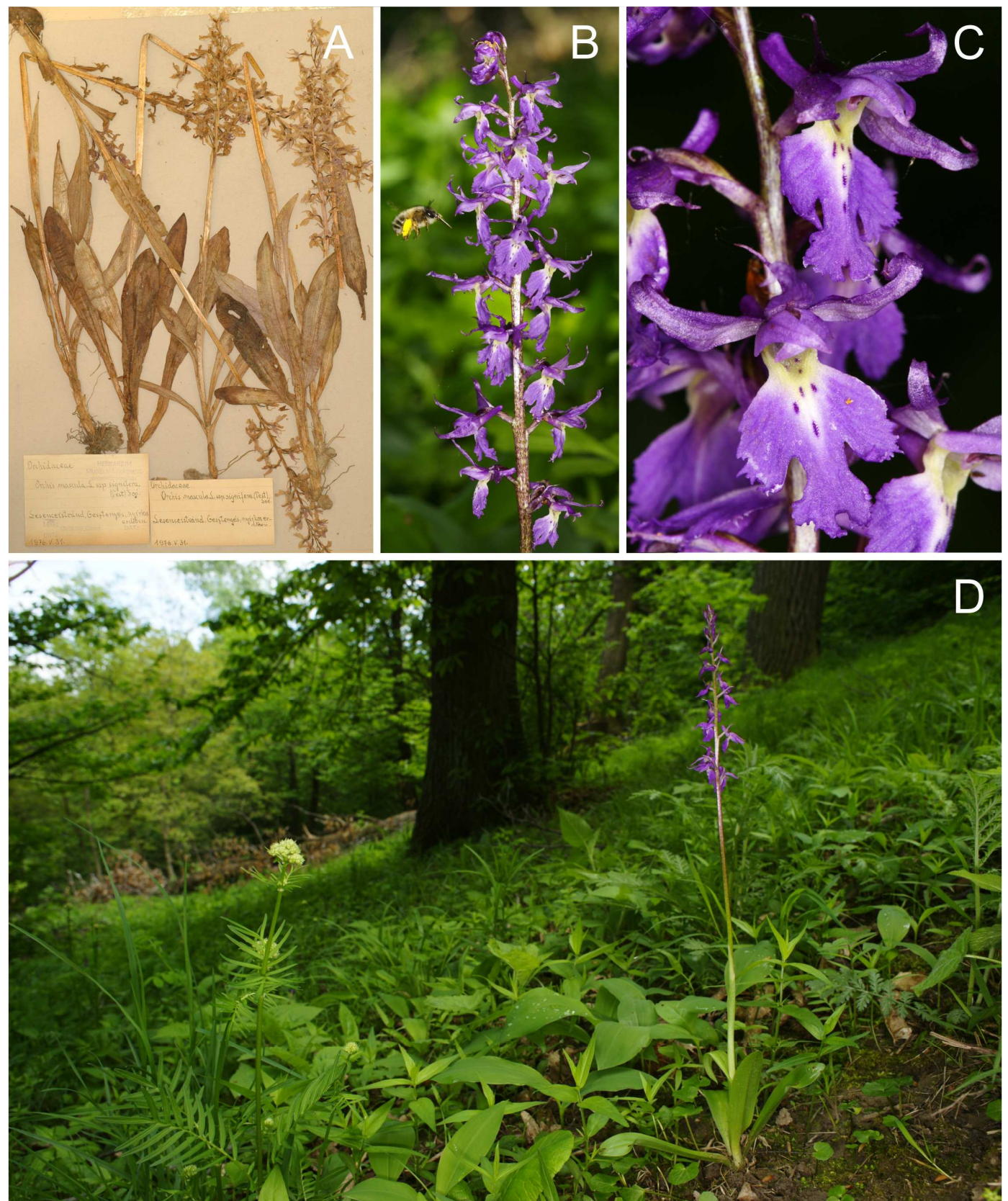

D

1. ábra. Az O. mascula subsp. signifera (A) lesenceistvándi bizonyító példánya a gyöngyösi Mátra Múzeum herbáriumában (gyűjtötte Gotthárd Dénes, 1976.05.31.; Magos Gábor felvétele), (B+C) 2015ben újrafelfedezett példányai és (D) termőhelyük (a szerző felvételei)

Fig. 1. (A) Voucher of $O$. mascula subsp. signifera from Lesenceistvánd (coll. D. Gotthárd, 31 May 1976, Mátra Museum, Gyöngyös; photo by G. Magos); $(\mathrm{B}+\mathrm{C})$ flowering specimens of the rediscovered population in 2015 and (D) its habitat (photos by the author) 


\section{A keszthelyi-hegységi állomány termőhelyi viszonyai és természetvédelmi problémái}

A lesencei termőhely az egykor kiterjedt, mára másodlagosan erdősülő gesztenyések utolsó, ma is jó természeti állapotban lévő maradványfoltja. A lesencei falvak szőlői a hegység keleti bazaltvonulatát képező Kő-orra - Láz-hegy déli, keleti lejtőinek löszköpenyén találhatók. A gesztenyések a meredek hegyoldalak kőfolyásainak és a lösztakarónak a találkozási zónájában húzódnak szalagszerűen, a természetes és a kultúrtáj mezsgyéjeként. Gotthárd gyüjtése idején a Keszthelyi-hegységben a gesztenyések minden bizonnyal sokkal nagyobb mértékben voltak hasznosítva, kezelve, így a faj termőhelye is nagyobb lehetett. Ám az utóbbi évtizedekben ezeknek a nyugat-dunántúli tájban jellemző élőhelyeknek a művelésével nagy területen felhagytak, így azokon többnyire a másodlagos szukcessziós folyamatok figyelhetők meg. Ennek során jellegtelen üde erdők alakulnak ki, melyben az idős, pusztuló Castanea sativa példányok alatt egy másodlagos fás szint fejlődik Carpinus betulus, Tilia cordata, Acer campestre, A. pseudoplatanus, A. platanoiodes, Prunus domestica fajokkal. A sűrű lombozat alatti megnövekedett árnyékolás, a kaszálás elmaradása és a túlszaporodott nagyvad állomány taposása, túrása következtében a korábbi fajgazdag gyepszint eltűnik, helyét néhány fajra redukálódott, jellegtelen állománynak (Brachypodium sylvaticum, Asarum europaeum, Ajuga reptans, Alliaria petiolata) adja át. Az Orchis mascula subsp. signifera lelőhelye is ilyen vegetációs környezetben található. A szomszédos területek aktuális élőhelyeinek (törmeléklejtő-erdők, akácosok, felhagyott gyümölcsösök) ismeretében a termőhely fennmaradása minden bizonnyal a különleges termőhelyi adottságoknak köszönhető: északi kitettség, felszínre törő források (némelyik az idős gesztenyék gyökerei között fakad) biztosította feltételek következtében az üde erdők gyepkompoziciója található. A nagyjából egy hektár területet egy tucatnyi idős, több száz éves Castanea sativa uralja. A gyepszint fajgazdag, természetes, ennek megfelelően több ritka, védett faj is megtalálható, mint az Astrantia major, Neotinea ovata, ill. a Gotthárd által innen szintén gyüjtött Tephroseris longifolia (syn.: Senecio ovirensis), melynek jelenleg ez az egyetlen ismert veszprém megyei előfordulása. Az inváziós fajok közül a Solidago gigantea néhány példánya volt megfigyelhető a közeli földúton. A termőhelyen készített cönológiai felvétel a következő $\left(160 \mathrm{~m}^{2}\right)$ :

A-szint: Castanea sativa 4, Tilia cordata 2, Carpinus betulus 2; C-szint: Brachypodium sylvaticum 1, Festuca heterophylla 1, Tussilago farfara +, Carex montana 1, Geum urbanum 1, Cornvallaria majalis 2, Carex sylvatica 2, Salvia glutinosa 2, Astrantia major 2, Valeriana officinalis 1, Glechoma hederacea 2, Ranunculus ficaria 1, Campanula persicifolia + , Symphytum officinale + , S. tuberosum + , Sanicula europaea + , Tanacetum corymbosum 1, Ajuga reptans 1, Viola sp. +, Hieracium sylvaticum +, Lathyrus vernus 1, L. niger +, Ranunculus auricomus 1, Aegopodium podagraria 2, Polygonum multiflorum 1, Allium ursinum 1, A. scorodophrasum +, Tamus communis 1, Listera ovata + , Orchis mascula subsp. signifera 1, Tephroseris longifolia +, Fragaria vesca 1, Rhumex acetosa 1, Eupatorium cannabinum 1, Lysimachia punctata 1, Melica uniflora 1.

Az Orchis mascula subsp. signifera keszthelyi-hegységi állományának fennmaradása több természetvédelmi problémát is felvet. A Kő-orra oldalában húzódó szőlőterületek gesztenyéseinek kezelése napjainkra megváltozott. Az intenzív kezelés esetében az évenkénti többszöri kaszálás, (2-3(-5)-szori gépi fünyírózás) a jellemző, a másik esetben a már említett, a művelés felhagyását követő szukcessziós folyamat jelentkezik. Mindkét szituációban a termőhelyi viszonyok és gyep fajkompoziciója drasztikusan megváltoznak, mely természetesen az Orchis mascula subsp. signifera túlélési feltételeit is behatárolják. A faj mindkét esetben rövid idő alatt eltűnik, hiszen a korai fünyírások (többnyire már áprilisban) a hajtások, a 2-3 éves ismétlésben a tövek, ill. az állomány teljes pusztulásához vezetnek. 
A másodlagos erdő kialakulásával együtt járó mély árnyékos termőhelyi körülmények is a faj eltűnéséhez vezetnek.

A füles kosbor lesencei állományának fennmaradása a sajátos termőhelyi viszonyok mellett a hagyományos extenzív kezelésnek köszönhető. Ez az évenkénti egy, esetleg kétszeri kaszálás. Az egyszeri kaszálást a gesztenyeérés előtti időben, ősz elején szokták elvégezni, a kétszeri kaszálás esetén az első munkálatokat a nyári hónapokra időzítették.

Az Orchis mascula subsp. signifera lesenceistvándi állományának fennmaradása azon múlik, hogy termőhelyén az eddigi kezelés a jövőben is folytatva lesz-e. Területi védelem a megfelelő kezelés nélkül semmilyen eredményre nem vezet.

\section{Köszönetnyilvánítás}

Ezúton szeretném megköszönni Bauer Norbertnek, Bérces Sándornak, Magos Gábornak, Molnár V. Attilának, Sulyok Józsefnek és Takács Attilának, hogy munkámat tanácsaikkal segítették.

\section{Irodalom}

MolnÁR V. A. (szerk.) (2011): Magyarország orchideáinak atlasza. - Kossuth könyvkiadó, Budapest.

Molnár V. A., Takács A., Horváth O., E. VojtKó A., Király G., Sonkoly J. \& SRAmKó G. (2012): Herbarium Database of Hungarian Orchids I. Methodology, dataset, historical aspects and taxa. - Biologia 67: 79-86.

Beérkezett / received: 2015. 08. 25. • Elfogadva / accepted: 2016. 06. 15. 